\title{
Mobilitas Migran Islam Jawa di Kuta Selatan Tahun 1974- 2017
}

\author{
Putu Dyah Pradnya Paramitha*, Sulandjari \\ Program Studi Sejarah Fakultas Ilmu Budaya Universitas Udayana \\ [prdmitha@yahoo.co.id], [solosulandjari@gmail.com] \\ Badung, Bali, Indonesia \\ *Corresponding Author
}

\begin{abstract}
This study discussed the dilemma of dependence and fear which was experienced by Hindus in South Kuta to the Javanese Islam migrant on 1974-2017. The problems of the study are formulated as follows: (1) Why is there a big amount of migrations in South Kuta? (2) How are the process and intensity of the migration happened in South Kuta? (3) What are the implications of fear and dependence of the Hindus in South Kuta to the Javanese Islam migrant?. This study used Social history methodology. The theory used in this study was the theory of migration proposed by Everett S.Lee. The result of the study revealed that there are a new finding in this study is the push factor of migration, religion factor, as a unifier, and work ethic (entrepreneurship) which happened to this Javanese Islam migrant. Another pull factor phenomena is the existence of various ceremony within the Hindus in South Kuta as well as the lifestyle of the South Kuta Hindus which is consumptive, hence they are easily used by this Javanese Islam Migrant.
\end{abstract}

Keywords: Social mobility, Tourism, Javanese Islam Migrant, Dependence, Fear.

\begin{abstract}
Abstrak
Studi ini membahas tentang sikap dilematis antara ketergantungan dan juga takut yang dialami masyarakat Hindu di Kuta Selatan terhadap dominasi migran Islam Jawa periode 1974-2017. Adapun rumusan masalah dalam studi ini meliputi (1) Mengapa terjadi migrasi dalam jumlah yang besar di Kuta Selatan? (2) Bagaimana proses dan intensitas migrasi terjadi di Kuta Selatan? (3) Apa implikasi dari takut dan tergantung masyarakat Hindu di Kuta Selatan dengan migran Islam Jawa. Dalam penelitian ini menggunakan metodologi sejarah sosial. Teori yang digunakan dalam penelitian ini adalah teori migrasi dari Everett S.Lee. Hasil penelitian mengungkapkan bahwa ada temuan baru dalam penelitian ini diantaranya adalah faktor pendorong migrasi yaitu faktor agama sebagai pemersatu dan etos kerja (kewiraswastaan) yang terjadi pada migran Islam Jawa ini. Fenomena yang lain pada faktor penarik yaitu adanya berbagai upacara pada masyarakat
\end{abstract}


Hindu di Kuta Selatan serta gaya hidup masyarakat Hindu Kuta Selatan yang konsumtif sehingga dapat dimanfaatkan oleh Migran Islam Jawa ini.

Kata kunci: Mobilitas sosial, Pariwisata, Migran Islam Jawa, Ketergantungan, Ketakutan.

\section{Latar Belakang}

Gelombang migrasi merupakan salah satu fenomena yang sangat penting dalam hubungan antar wilayah atau daerah. Menurut Nyoman Tama, perubahanperubahan itu mulai terlihat setelah berdirinya PT. Bali Tourism Development Corporation (BTDC) di Nusa Dua, kecamatan Kuta Selatan.

Pembangunan kontruksi dan infrastruktur kawasan pariwisata Nusa Dua dimulai sejak tahun 1974-1979. Dalam periode yang relatif pendek ini ekonomi Bali semakin tergantung pada industri turis. Perubahan-perubahan sosial meliputi arus masuk perantau Islam secara besar-besaran terutama dari Jawa.

Pada tahun 1997-1998, Indonesia dilanda krisis ekonomi dan moneter. Roda perekonomian masyarakat Bali masih bisa berputar karena adanya pariwisata yang memang sedang booming-nya di tahun 1991. Wacana ini terdengar jelas di Jawa, sehingga hal inilah juga menjadi salah satu penyebab lebih banyak lagi migran Islam Jawa yang datang ke Bali.

Kelangkaan Sumber Daya Manusia Bali menyebabkan satu-satunya pilihan untuk mengisi beberapa pekerjaan dalam sektor informal, seperti pedagang kaki lima, pedagang asongan, dan buruh bangunan (Ary Dwipayana, 2005:65-66). Berbekal kemauan dan tekad yang kuat, mereka lakukan melalui berdagang, baik itu barang maupun jasa.

Berdasarkan hal tersebut dan pemaparan-pemaparan yang telah disampaikan sebelumnya penulis mengkaji pengaruh dominasi migran Islam Jawa dalam sektor informal terhadap masyarakat Hindu di Kuta
Selatan secara lebih mendalam pada sebuah penelitian yang berjudul, Mobilitas Migran Islam Jawa di Kuta Selatan Tahun 1974-2017.

\section{Pokok Permasalahan}

Berdasarkan latar belakang di atas, dapat dirumuskan permasalahan sebagai berikut:

a) Mengapa terjadi migrasi dalam jumlah yang besar di Kuta Selatan?

b) Bagaimana proses dan intensitas terjadinya migrasi di Kuta Selatan?

c) Apa implikasi dari takut dan tergantung masyarakat Hindu di Kuta Selatan dengan migran Islam Jawa?

\section{Tujuan Penelitian}

Adapun tujuan penelitian ini, sebagai berikut:

a) Mengetahui bagaimana proses datangnya migran Islam Jawa ke Bali dan mampu menguasai sektor-sektor informal.

b) Menggambarkan bagaimana terjadinya proses dilematis yang dialami masyarakat Hindu di Bali bagian Selatan, khususnya kecamatan Kuta Selatan terhadap dominasi migran Islam Jawa.

c) Menggambarkan implikasi adanya perlawanan atau kebangkitan masyarakat Hindu di Kuta Selatan terhadap migran Islam Jawa.

\section{Metode Penelitian}

Penelitian yang dilakukan berpedoman pada metode sejarah seperti yang diajarkan oleh Louis Goutchalk. Heuristik atau mencari dan menemukan sumber merupakan langkah awal dalam melakukan penelitian. Peneliti mencari dan menemukan sumber dengan cara 
wawancara lisan. Adapun metode purposive sampling yakni pilihan yang disengaja karena seorang informan memiliki kualitas pantas untuk diteliti.

Sumber sekunder yang digunakan antara lain referensi buku-buku yang relevan dengan skripsi, sumber tertulis atau dokumen, tulisan catatan harian, jurnal, dan hasil liputan koran.

Kritik sumber ada dua yaitu kritik internal dan kritik eksternal. Kritik internal dalam penelitian ini, informasi yang sudah sekian informasi melalui wawancara terencana maupun tidak terencana diteliti atau diuji dengan membandingkan informasi satu dengan yang lainnya sedangkan kritik eksternal dalam penelitian ini, penulis membandingkan sumber buku lainnya, hal ini digunakan sebagai data penguat dan koreksi.

Interpretasi (menafsirkan data) dalam penelitian ini penulis menghubungkan secara kronologis semua data dan informasi yang sudah ditafsirkan sehingga menjadi rangkaian peristiwa yang logis.

Hitoriografi atau merekontruksi ulang sejarah merupakan tahap akhir dari metode penelitian sejarah yaitu penyajian dalam bentuk penulisan sejarah yang berdasarkan fakta-fakta yang terpisah antar satu dengan yang lainnya.

Data yang diperoleh seperti hasil wawancara, hasil pengamatan, dokumen berupa arsip, gambar, dan sumber pustaka yang berkaitan dengan penelitian ini.

\section{Hasil dan Pembahasan}

\subsection{Faktor Faktor-Faktor Penyebab Terjadinya Mobilitas Migran Islam Jawa Di Kuta Selatan \\ 5.1.1 Faktor Pendorong}

\section{a. Etos Kerja Migran Islam Jawa}

Migran Islam Jawa di Bali terkenal memiliki etos kerja rajin, ulet, dan mau bekerja keras di dasari oleh motivasi yang tinggi untuk memperbaiki nasib. "Sedikit-sedikit lama-lama menjadi bukit".

Berbekal kemauan dan tekad yang kuat, mereka lakukan melalui berdagang, baik itu barang maupun jasa. Salah satu contohnya hampir setiap malam deretan pedagang makanan berjamur menghiasi sudut kota dan sebagian besar usaha makanan itu dimiliki oleh para pendatang Islam Jawa ini khususnya.

\section{b. Agama Islam Sebagai Pemersatu}

Seorang muslim boleh saja membeli apa yang diperlukan tentunya yang dihalalkan. Hanya saja berbeda dengan di Bali yang notabene mengkonsumsi daging babi. Hal ini tentu saja membuat migran Islam Jawa enggan membeli makanan jadi di masyarakat lokal.

Secara tidak langsung, pandangan ini membuat terjadinya kesejangan ekonomi diantara masyarakat lokal. Permasalahan ini mengakibatkan warung-warung makanan siap saji masyarakat Hindu di Kuta Selatan jarang bahkan tidak memiliki konsumen Muslim. Sedangkan, migran Islam Jawa, pasti akan membeli dan makan di tempat sesamanya.

\section{c. Ikatan Kekeluargaan Dan Daerah Asal}

Ada tradisi atau kebiasaan setelah merayakan Lebaran di kampung halaman, migran Islam Jawa ini akan mengajak kerabat untuk mengadu nasib di Bali. Fenomena ini sudah berlangsung lama sejak tradisi mudik itu sendiri dimulai. Migran Islam Jawa yang dianggap sukses "menaklukkan" Bali adalah harapan tersendiri bagi kerabat di kampung halaman untuk mengikuti jejak kesuksesan mereka. Inilah yang menjadi penyebab tingginya angka migrasi dari Jawa ke Bali yang dimulai pascaLebaran. 


\section{d. Tekanan Ekonomi di Daerah Asal Migran}

Beberapa studi di beberapa tempat di Indonesia, mengatakan dalam salah satu "hukum" migrasi, bahwa motif ekonomi merupakan dorongan utama untuk seseorang atau kelompok untuk mengambil keputusan melakukan migrasi. Sudah bertahun-tahun lamanya prosentase yang paling besar diantara para migran ini adalah mereka yang miskin dan kekurangan, tidak mempunyai tanah atau sawah, mereka yang tidak mempunyai keterampilan, serta di desanya tidak ada lagi kesempatan untuk bekerja.

\section{e. Rendahnya Tingkat Pendidikan Migran Islam Jawa}

Para migran Islam Jawa di Kuta Selatan rata-rata berpendidikan rendah maksimal SLTP. Tingkat pendidikan yang rendah mengakibatkan sulitnya mendapatkan pekerjaan yang memadai. Rendahnya tingkat pendidikan, bersamaan dengan kurangnya keterampilan yang dimiliki berdampak pada kurang terserapnya para pekerja di daerah asal. Oleh karena itu para migran yang datang ke daerah baru lebih banyak bergerak di sektor informal. Kebetulan sektor informal di Kuta Selatan tidak banyak diganti oleh penduduk lokal.

\section{f. Akses Transportasi dan Informasi}

Transportasi antara Jawa dan Bali sekarang sangat lancar dan murah mendorong migran cepat memutuskan untuk pergi merantau ke Kuta Selatan. Informasi teman dan saudara merupakan pola yang utama kedatangan para migran Islam ke Kuta Selatan. Ketika para perantau kembali mudik ke kampung halaman membawa cerita-cerita kesuksesan di tempat yang baru. Bahkan ada kesan mereka biasanya agak "pamer" tentang keberhasilan dirantau.

\subsubsection{Faktor Penarik}

a. Adanya Pembangunan Fisik di Kuta Selatan

Pengembangan suatu wilayah, diperlukan dukungan infrastruktur yang memadai. Infrastruktur merupakan mediator vital untuk menunjang taraf sosial ekonomi dan lingkungan budaya dalam suatu masyarakat. Begitu halnya dengan pengembangan industri pariwisata di wilayah Kuta Selatan. Pengembangan infrastruktur berupa jalan, penyediaan air bersih, dan tenaga listrik, sebagai strategi utama untuk menarik partisipasi masyarakat, dalam proses pembangunan di Kuta Selatan. Infrastruktur yang layak merupakan hal penting dalam mendorong kualitas pariwisata di Kuta Selatan dan wilayah sekitarnya.

\section{b. Booming Pariwisata di Kuta Selatan}

Faktor penarik yang utama kedatangan para migran Islam Jawa ke Kuta Selatan adalah sektor pariwisata. Dalam sektor pariwisata, tenaga kerja Islam Jawa memasok keperluan hotel dan restoran seperti telur, daging, sayur, dan aneka buah-buahan yang didatangkan dari Jawa Timur seperti dari Banyuwangi, Jember yang masih menghasilkan buah dan sayur dan juga pasokan daging terutama ayam. Aneka kebutuhan ini tidak bisa dicukupi di Bali, karena daerah Bali lahan-lahan pertanian sangat terbatas, tidak seperti di Jawa yang lahannya relatif masih luas.

\section{c. Adanya Berbagai Upacara dan Upakara Masyarakat Hindu}

Masyarakat Hindu di Kuta Selatan terbiasa hidup mewah semenjak menjual tanah-tanahnya. Hal ini menimbulkan masalah budaya yaitu kebiasaan hidup mewah dan konsumtif.

Migran Islam Jawa mengambil kesempatan dengan menjual sarana dan prasarana upakara dan upacara masyarakat Hindu di Kuta Selatan. Jika 
pada masa lalu buah dan sayuran dengan mudah dapat dipetik di kebun, sekarang membeli buah harus di pasar dan swalayan yang didatangkan dari Jawa. Janur pun, sebagai alat utama upacara juga didatangkan dari Jawa, bersama sayur dan bunga.

\section{d. Gaya Hidup Masyarakat Hindu di Kuta Selatan}

Masyarakat lokal yang menjual tanah menjadi masyarakat yang konsumtif. Dampak yang paling buruk sebenarnya dari menjual tanah adalah melahirkan masyarakat yang konsumtif dan tidak produktif. Secara psikologis, masyarakat menjadi malas dan manja karena setelah mereka tidak lagi mempunyai uang kehidupannya jadi tidak menentu. Wacana ini yang dibaca atau ditangkap oleh migran Islam Jawa dengan mengambil kesempatan untuk tetap menggeluti sektor informal

\subsection{Proses Terjadinya Mobilitas Migran Islam Jawa Di Kuta Selatan}

\subsubsection{Kedatangan Migran Islam Jawa}

Pembangunan kontruksi dan infrastruktur kawasan pariwisata Nusa Dua dimulai sejak tahun 1974-1979. Dalam periode yang relatif pendek ini ekonomi Bali semakin tergantung pada industri turis. Perubahan-perubahan sosial meliputi arus masuk perantau Islam secara besar-besaran terutama dari Jawa.

\subsubsection{Kondisi Sosial Ekonomi Migran Islam Jawa}

Kemiskinan merupakan masalah yang kerap timbul di hampir semua negara, terutama di Indonesia. Ini ditandai dengan keadaan lahan yang gersang dan tidak subur serta didukung pula oleh kurangnya lapangan pekerjaan di kampung halaman yang menjadi faktor pendorong (push factor) migran Islam
Jawa untuk bermigrasi ke Bali. Di samping itu, adanya daya tarik (full factor) Bali yang memberikan kesempatan kerja yang lebih besar. Booming pariwisata memang sangat mempengaruhi adanya migrasi ini. Migran Islam Jawa pergi meninggalkan kampung halamannya untuk mecari pekerjaan dengan harapan dapat menambah pendapatan dan meningkatkan status sosialnya di kampung halaman.

\subsubsection{Penyebaran Migran Islam Jawa}

Migran Islam Jawa periode 1990, hanya mendiami wilayah Nusa Dua dan sekitarnya akibat lonjakan drastis pariwisata. Dimulai dengan bekerja pada sektor-sektor tenaga kerja kasar atau pekerja borongan proyek Nusa Dua dan sekitarnya.

\subsubsection{Jenis-Jenis Usaha Yang Bisa Menjangkau Migran Islam Jawa}

Sebagian besar migran Islam Jawa di Bali bagian Selatan mengais rejeki di sektor informal. Hal ini selaras dengan apa yang terjadi di salah satu wilayah Bali bagian Selatan yaitu desa Ungasan. Sebagian besar migran Islam Jawa yang menetap di wilayah Kuta Selatan bergerak pada sektor informal.

\subsubsection{Kondisi Sosial Ekonomi Migran Islam Jawa Tingkat Lanjut \\ Migran Islam Jawa berikutnya akan} merantau dan tinggal di tempat keluarganya yang sudah lama berada di Bali, namun apabila sudah mandiri mereka akan keluar dari tempat keluarga atau sanak saudaranya dan mencari tempat tinggal sendiri. Dengan jumlah yang sedikit di perantauan, mereka akan menganggap semua adalah saudara dan akan saling membantu bila ada kesusahan diantara mereka.

Perlahan tapi pasti, berkat strategi adaptasi migran Islam Jawa dari aspek sosial dan ekonomi, menjadikan mereka 
tidak dianggap lagi sebagai pendatang. Kerukunan yang bisa dilihat dari penggunaan bahasa Bali yang menyebut orang Islam dengan istilah nyama selam yang berarti saudara Islam (I Made Pageh, 2013:30-33).

\subsubsection{Penyebaran Migran Islam Jawa Tingkat Lanjut}

Sejak dibangunnya hotel-hotel di kawasan Nusa Dua berdampak kepada pembangunan kawasan wilayah perbukitan antara lain: Bualu, Kampial, Kutuh, Ungasan, dan Pecatu. Masyarakat Hindu di Bali bagian Selatan mengalami perubahan yang drastis sejak masuknya pariwisata pada tahun 1980 dan menjad booming pada tahun 1990. Migran Islam Jawa pun mulai menyebar, tidak lagi berpusat di Nusa Dua saja. Mereka mulai masuk ke wilayah-wilayah yang terkena dampak booming-nya pariwisata.

\subsubsection{Sikap Dilematis \\ Ketergantungan dan Ketakutan Antara Migran Islam Jawa dengan Masyarakat Hindu di Kuta Selatan}

Suatu hal yang sangat menarik, terdapat sifat kontradiktif masyarakat Bali khususnya Kuta Selatan terhadap para migran Islam yaitu ketergantungan dan ketakutan. Ketakutan terjadi ketika para migran menguasai hampir semua sektor ekonomi yang ada. Dari pedagang kecil sampai pedagang besar, dari menyediakan kebutuhan sehari-hari sampai sarana upacara dan upacara dalam agama Hindu. Dari segi penduduk, para migran sudah mendekati keseimbangan.

Tidak terlepas dari itu dengan meningkatnya para migran yang datang ke Bali, mengenai kebutuhan akan lahan tempat tinggal menimbulkan problem bagi migran Islam Jawa ini. Di sini masyarakat Hindu khususnya kecamatan Kuta Selatan sangat diuntungkan, migran Islam Jawa sangat bergantung kepada masyarakat lokal, terutama untuk menyewa atau kost dan membeli atau menyewa tanah untuk membangun rumah dan tempat usaha.

\subsection{Implikasi Dari Ketergantungan Dan Ketakutan Masyarakat Hindu Di Kuta Selatan Terhadap Migran Islam Jawa}

\subsubsection{Kebijakan Pemerintah dengan Desa Adat dan Agama}

Penanganan masalah keamanan bagi masyarakat Hindu di Kuta Selatan menjadi prioritas utama, karena jumlah penduduk semakin bertambah, semakin heterogen, dan semakin kompleks yang nantinya dapat mengganggu ketentraman dan ketertiban masyarakat yang memungkinkan terjadinya kerawanan sosial. Untuk itu membatasi pendatang liar saat itu perlu adanya razia-razia KIPEM, KTP, dan KIPP yang wajib dilakukan desa adat dan pecalang kepada penduduk pendatang.

\subsubsection{Ajeg Bali}

Berbekal "pembenaran" istilah Ajeg Bali, tersebar perdebatan yang berujung pada sebuah tekad untuk menjaga Bali. Muncul semangat patriotisme primordial sehingga muncul gagasan: Bali adalah milik orang Bali, Bali harus dijaga, kembali ke budaya dan agama Bali.

Oleh karena itu, langkah kecil yang dapat dilakukanjika memang sektor ekonomi tak ingin dikuasai migran Islam Jawa, masyarakat lokal sebaiknya mulai mengisi sektor-sektor informal dan harus memiliki sifat jengah serta membuang jauh rasa gengsi yang menjadi penghambat kemajuan.

\subsubsection{Kebangkitan Masyrakat Hindu di Kuta Selatan}

\subsubsection{Dalam Bidang Usaha}

Kebangkitan masyarakat Hindu di Kuta Selatan bisa dimulai dari menghilangkan sifat gengsi yang sudah 
melekat di diri masyarakat untuk mulai memilih jenis usaha yang cocok dan menjanjikan. Bisnis yang menjanjikan dalam arti usaha yang memiliki peluang mendatangkan keuntungan maksimal dengan modal rendah serta prospektif paling tidak untuk lima tahun mendatang.

\subsubsection{Kemampuan Berinvestasi}

Melonjaknya pariwisata membuat masyarakat lokal memilih untuk ikut membangun sarana penunjang pariwisata, yaitu dengan mendirikan dengan membangun rumah-rumah kost (rumah sewa-kontrak) untuk migran Islam Jawa yang membutuhkan tempat tinggal.

\subsubsection{Manfaat-manfaat Ekonomi}

\subsubsection{Jumlah Rumah Sewa, Kontrakan, dan Rumah Kos}

Melonjaknya pariwisata membuat masyarakat lokal memilih untuk ikut membangun sarana penunjang pariwisata, yaitu dengan mendirikan dengan membangun rumah-rumah kost (rumah sewa-kontrak) untuk migran Islam Jawa yang membutuhkan tempat tinggal. Selain itu masyarakat Hindu di Kuta Selatan juga mendirikan warung, rumah makan, dan restoran untuk disewa atau dikontrakkan kepada migran Islam Jawa.

\subsubsection{Terkikisnya Kearifan Lokal}

Perkembangan pariwisata yang pesat di Kuta Selatan, memberi dampak besar pada kearifan lokal masyarakat Kuta Selatan. Pengkajian mengenai perkembangan teknologi yang disertai bertemunya berbagai jenis kebudayaan yang dibawa oleh para wisatawan dan para pekerja dari luar wilayah kepulauan Bali, menyebabkan interaksi kebudayaan tanpa disadari diadopsi oleh masyarakat lokal.

\section{Simpulan}

Adanya faktor pendorong (push factor) migran Islam Jawa untuk bermigrasi ke Bali. Di samping itu, adanya daya tarik (full factor) Bali yang memberikan kesempatan kerja yang lebih besar.

Sikap dilematis antara ketergantungan dan juga takut yang dialami masyarakat Hindu di Kuta Selatan terhadap dominasi migran Islam Jawa. selain adanya ketergantungan ada juga perasaan takut masyarakat lokal akan kehadiran dari migran Islam Jawa ini. Migran Islam Jawa ini lamakelamaan dikhawatirkan akan menggusur dominasi masyarakat Hindu di Kuta Selatan. Oleh sebab itu diperlukan tindakan nyata dalam meningkatkan kualitas jengah masyarakat Hindu di Kuta Selatan terhadap migran Islam Jawa.

\section{Saran}

Pertama, untuk masyarakat Hindu di Kuta Selatan, agar menghilangkan perasaan "gengsi" dalam bidang pekerjaan. Memupuk kembali rasa jengah sebagai etos kerja dari masyarakat Hindu di Kuta Selatan.

Kedua, masyarakat Hindu juga tidak perlu melakukan upacara secara besarbesaran sampai menjual aset tanah. Upacara keagamaan dapat disederhanakan, yang terpenting tetap menjaga esensinya.

Ketiga, Pemerintah daerah sangat perlu "memfilter" para migran yang tidak mempunyai pekerjaan dengan persyaratan kependudukan sesuai dengan Undang-undang.

Bagi peneliti-peneliti lanjutan yang ingin melakukan penelitian berkaitan dengan migran Islam Jawa terutama di wilayah Bali Selatan diharapkan agar mengkajinya lebih mendalam sehingga memperoleh gambaran jelas. 


\section{Daftar Pustaka}

Burhanuddin, Yudhis M. 2008. Bali Yang Hilang: Pendatang, Islam, dan Etnisitas di Bali. Yogyakarta: Kanisius.

Dwipayana, Ary. 2005. Globalism: Pergulatan Politik Representasi atas Bali. Denpasar: Uluangkep Press.

Haris, Abdul. 2005. Gelombang Migrasi \& Jaringan Perdagangan Manusia. Yogyakarta: Pustaka Pelajar.

Kesuma, Andi Ima. 2004. Migrasi \& Orang Bugis. Yogyakarta: Penerbit Ombak.

Lee, Evert S. "A Theory of Migration", dalam Demography, Volume 3. No. $1,1966$.

Manning, J. Chris dan Tadjuddin Noer Effendi. 1985. Urbanisasi, Pengangguran, dan Sektor Informal di Kota. Jakarta: Gramedia Pustaka Utama.

Mashad, Dhurorudin. 2014. Muslim Bali: Mencari Kembali Harmoni yang Hilang. Jakarta: Pustaka AlKautsar.

Nordholt, Henk Schulte. 2007. Bali Sebuah Benteng Terbuka dalam buku Politik Lokal di Indonesia. Jakarta: Yayasan Pustaka Obor Indonesia.

Speech Mr. Wiweko at Opening of Nusa Dua Beach Hotel, Desember 17, 1982 (Dokumen Koleksi Arsip Nasional Republik Indonesia). 2018. 